\title{
THE ANALYSIS OF THE BANKRUPTCY OF ENTERPRISES EXEMPLIFIED BY THE VISEGRAD GROUP
}

\author{
Jarosław KRAJEWSKI ${ }^{\circledR}$, Andrzej TOKARSKI ${ }^{(D *}$, Maciej TOKARSKI ${ }^{\mathbb{D}}$ \\ Faculty of Finance and Management, WSB University in Torun, Torun, Poland
}

Received 04 June 2019; accepted 23 January 2020

\begin{abstract}
The phenomenon of enterprises bankruptcy is an extremely complex process of economic, legal, social and even psychological nature. In the developed countries, the first studies on forecasting bankruptcy date to the early 20th century. In Central and Eastern Europe, due to, among other factors, the geopolitical situation and the introduced economic system, this issue became the subject of researchers' interest only in the 1990s. The universality and complexity of the phenomenon incline the Authors to make an attempt to identify the scale of the bankruptcy processes in the states of the Visegrad Group (V4). The countries of V4 were selected because of their common history and similar economic development. The aim of this article is to analyze the dynamics of the phenomenon of bankruptcy of enterprises in the states of the V4 Group in the years 2005-2016 on the basis of the data taken from the Credit reform reports. The estimation of trend models in time series on the basis of the bankruptcy in the Visegrad Group countries in the years 2005-2016 was used in the article as the primary research method. The descriptive analysis was also applied in the article.
\end{abstract}

Keywords: bankruptcy, company insolvency, business failure, Visegrád Group, trend models, time series analysis, comparative analysis, bankruptcy of enterprises in V4 countries.

JEL Classification: C22, G32, G33, D20.

\section{Introduction}

The phenomenon of bankruptcy is an indispensable element of any market economy and may concern any business (Matuszak \& Tokarski, 2016). Although the current political, economic and legal system of a country influences the level and structure of bankruptcy, it is widespread and is constantly accompanying national economies. The ongoing processes of globalization and the internationalization of business have resulted in greater dependence and interconnections between businesses, often resulting in bankruptcy in the economically connected countries (Mączynska, 2013).

The phenomenon of corporate bankruptcy is an extremely complex process of economic, legal, social and even psychological nature. Depending on the size of the business unit and

*Corresponding author. E-mails andrzej.tokarski@wsb.torun.pl 
the extent of its activity, it can have international, national or local impact, involving and influencing many parties involved in insolvency proceedings (Mączyńska \& Morawska, 2015).

The need for the constant monitoring of the phenomenon of business bankruptcy in a given economy, and nowadays also increasingly also of households (i.e. consumer bankruptcy), stems primarily from the fact that the smooth operation of these processes is an intrinsic part of an effective market economy (Matuszak \& Tokarski, 2016a).

Bankruptcy and insolvency of enterprises are an inherent phenomenon in the market economy, whose scope, size, dynamics and intensity alter along with the changes in the both closer and further business environment, as well as in the global economy (Tokarski \& Matuszak, 2016).

The complexity and universality of the phenomenon encouraged the Authors of the article to attempt to identify the scale of the bankruptcy proceedings present in the states of the Visegrad Group. The countries of Visegrad Four were selected because of their common history and similar economic development (Piotrowicz, 2015; Kořan, 2012). A similar historical development among these post-communist countries is reflected in the development of their insolvency laws. At present, the insolvency systems of the V4 countries are largely similar (Crhova et al., 2016). In 2019, 28 years has passed since the signing of the Visegrad Declaration and the creation of the Visegrad Triangle. The Visegrad Group has been a platform for the regional cooperation, the foundation of which is the common historical heritage and similar geopolitical situation of the Central European countries as well as the awareness of the convergence of challenges they face. For 28 years of its existence, it has developed a positive tradition of cooperation between its neighbours and it is commonly treated as an optimal formula for cooperation at the regional level. The V4 Group proved its usefulness as a platform for the articulation of the Central European interests and the core of broader political coalitions, above all on the EU forum. This has been particularly evident in the cooperation of the Group with other EU countries in the „V4+” format, for example with the Baltic States, Romania, Bulgaria, Slovenia, and with Croatia. The role of the Visegrad Group in bringing together political elites and societies of states that are not free form historical past and also in the alleviation of current political disputes that appear form time to time in neighbourly relations also should not be underestimated (Bukalska, 2003; Dangerfield, 2014, 2005; Jagodzinski, 2006; Baun \& Marek, 2010; Ručinská \& Fečko, 2016).

The main aim of the paper is to analyze the dynamics of the phenomenon of bankruptcy of enterprises in V4 states. The annual statistical data sets in the form of the time series characterising the bankruptcy of enterprise were used in the analysis. The data in question concerned the years from 2005 to 2016 inclusive, so each time series consisted of 11 observations. All data were taken from the Creditreform reports. The descriptive method was also used in the article. Various reference books on the bankruptcy of enterprises were also used in the analysis.

The content and process structure of the paper were defined in order to meet the research objectives. The introductory part consists of presenting the significance of the issue of bankruptcy and insolvency of enterprises in the economy, defining the purpose, structure and research methods used in the article. Next, the literature on the subject was reviewed in the field of research areas and approaches regarding the bankruptcy of enterprises. The discussed issues constitute an important area of empirical research, which is confirmed by numerous 
scientific studies. It is the subject of theoretical considerations and empirical research in all countries with a free market economy. As the free-trade economy cannot exist without the possibility of declaring bankruptcy. In the following part an empirical analysis of the dynamics of enterprise bankruptcy in the V4 countries was conducted. The indexes of dynamics and the estimation of trend models based on the time series concerning the bankruptcy of enterprises of the Visegrad Group countries in the years 2005-2016 were used in that part of the research. The statistical data gathered from the Creditreform database was used in the analysis. The trend analysis allows you to examine the general trends occurring within the studied phenomenon. In most cases the degree of fitting the models to the empirical data indicated by the $\mathrm{R}^{2}$ determination coefficients indicate their high practical utility. The obtained econometric tools can be used to predict the analyzed variable. In the summary, the authors also call for the practical and scientific applicability of the results and the need for a continuous research in this field. Finally, the authors evaluate the achievement of the aims of the paper and they discuss its further research potential.

This paper consists of five parts. The Introduction section presents the basic ground for the research, followed by detail literature reviews in section 1 . While section 2 presents the models and the empirical results of the dynamics of the bankruptcy of enterprises, section 3 shows the analysis of the effectiveness of the bankruptcy system of the Visegrad Group countries in relation to the European Union countries. The final section concludes the paper.

\section{The overview of the literature}

The issues of bankruptcy of enterprises constitute a significant area of empirical studies, as numerous research papers prove (Mačerinskienè \& Mendelsonas, 2013).

There have been many empirical and theoretical research studies conducted in the field of bankruptcy and insolvency of the business entities throughout decades as well as in different countries and different branches of economy, which leads to various conclusions (Tokarski, 2018). The research on bankruptcy was conducted with consideration of several areas and various approaches (Hart, 2000; Wang, 2006).

According to Wang (2006, p. 4) the scientific researches on the phenomenon of bankruptcy focus on four main areas:

- the changes concerning the corporate governance in the menace of bankruptcy,

- the costs of bankruptcy,

- the prices of shares and the long-term results,

- the changes in the legal regulations concerning bankruptcy.

Many of the research studies were focused on the forecast of the bankruptcy of enterprises (Altman \& Hotchkiss, 2006; Prusak, 2018; Durica et al., 2019a, 2019b; Kliestik et al., 2018).

\section{The empirical analysis of the dynamics of the bankruptcy of enterprises in the member states of the Visegrad Group in the years 2005-2016}

The scale of the bankruptcy phenomena and the fact that the efficiency of the bankruptcy proceedings is taken into consideration while assessing the effectiveness of the national 
economies prove that the significance of the bankruptcy in the modern economy is on the increase (A. Tokarski \& M. Tokarski, 2018). Even though bankruptcy is not a mass phenomenon, it occurs frequently enough so that it cannot be deemed as irrelevant. The statistics concerning the bankruptcy gives evidence to the significant scale of that phenomenon (Tomczak, 2018; A. Tokarski \& M. Tokarski, 2019).

The main aim of the empirical part of the paper is to analyse the dynamics of the bankruptcy of the enterprises in the Visegard Group member states. The annual data sets in the form of time series (Baltagi, 2001) which characterise the phenomenon of the bankruptcy of enterprises in Czech Republic, Poland, Slovakia and Hungary were utilised in the conducted research. The data related to the period from 2005 to 2016 inclusive, so each time series consisted of 11 observations. All data was taken from the Creditreform ${ }^{1}$ reports and their summary is presented in Table 1.

Table 1. The number of the bankruptcy of enterprises in the Visegrad Group countries in the years 2005-2016 (source: Own work on the basis of Creditreform.de, 2018)

\begin{tabular}{|c|c|c|c|c|}
\hline Year & Czech Republic & Poland & Slovakia & Hungary \\
\hline 2005 & 3882 & 793 & 2200 & 7983 \\
\hline 2006 & 4227 & 576 & 2150 & 9447 \\
\hline 2007 & 4250 & 447 & 2100 & 9500 \\
\hline 2008 & 4600 & 425 & 582 & 11322 \\
\hline 2009 & 8394 & 590 & 900 & 14637 \\
\hline 2010 & 5559 & 665 & 830 & 17487 \\
\hline 2011 & 6753 & 762 & 870 & 30757 \\
\hline 2012 & 8398 & 908 & 866 & 50224 \\
\hline 2013 & 6021 & 926 & 880 & 46398 \\
\hline 2014 & 3563 & 864 & 831 & 60637 \\
\hline 2015 & 3004 & 844 & 715 & 47131 \\
\hline 2016 & 2438 & 597 & 692 & 41007 \\
\hline
\end{tabular}

Before estimating the trend models, the analysis of the dynamics of bankruptcy in the V4 countries was made with the use of the following measures (Aczel, 2012):

- one-base indices informing how the individual numerical values have changed in relation to the base year taken as the basis for comparisons:

$$
I_{t / 0}=\frac{y_{t}}{y_{0}} \cdot 100
$$

where: $y_{t}$ - value of a specific variable in the period under consideration; $y_{0}$ - value of a specific variable in the base period.

- a chain index informing how the individual numerical values have changed in relation to the year preceding the year being the subject of the analysis:

\footnotetext{
$\overline{{ }^{1} \text { https://www.creditreform.at/presse/insolvenzstatistik-europa.html }}$
} 


$$
I_{t / t-1}=\frac{y_{t}}{y_{t-1}} \cdot 100,
$$

where $y_{t-1}$ - value of a specific variable in the previous period.

The year 2005 was adopted as the base year in the one-base indices, which is the first of the collected numerical observations. The results of the calculations are presented in the following tabular statements.

Table 2. The chain indices of the number of bankruptcies in the Visegrad Group countries (source: Own work)

\begin{tabular}{|c|c|c|c|c|}
\hline Year & Czech Republic & Poland & Slovakia & Hungary \\
\hline 2006 & 108.89 & 72.64 & 97.73 & 118.34 \\
\hline 2007 & 100.54 & 77.60 & 97.67 & 100.56 \\
\hline 2008 & 108.24 & 95.08 & 27.71 & 119.18 \\
\hline 2009 & 182.48 & 138.82 & 154.64 & 129.28 \\
\hline 2010 & 66.23 & 112.71 & 92.22 & 119.47 \\
\hline 2011 & 121.48 & 114.59 & 104.82 & 175.88 \\
\hline 2012 & 124.36 & 119.16 & 99.54 & 163.29 \\
\hline 2013 & 71.70 & 101.98 & 101.62 & 92.38 \\
\hline 2014 & 59.18 & 93.30 & 94.43 & 130.69 \\
\hline 2015 & 84.31 & 97.69 & 86.04 & 77.73 \\
\hline 2016 & 81.16 & 70.73 & 96.78 & 87.01 \\
\hline
\end{tabular}

Table 3. One-base indices of the number of bankruptcies in the Visegrad Group countries (source: Own work)

\begin{tabular}{|c|c|c|c|c|}
\hline Year & Czech Republic & Poland & Slovakia & Hungary \\
\hline 2006 & 108.89 & 72.64 & 97.73 & 118.34 \\
\hline 2007 & 109.48 & 56.37 & 95.45 & 119.00 \\
\hline 2008 & 118.50 & 53.59 & 26.45 & 141.83 \\
\hline 2009 & 216.23 & 74.40 & 40.91 & 183.35 \\
\hline 2010 & 143.20 & 83.86 & 37.73 & 219.05 \\
\hline 2011 & 173.96 & 96.09 & 39.55 & 385.28 \\
\hline 2012 & 216.33 & 114.50 & 39.36 & 629.14 \\
\hline 2013 & 155.10 & 116.77 & 40.00 & 581.21 \\
\hline 2014 & 91.78 & 108.95 & 37.77 & 759.58 \\
\hline 2015 & 77.38 & 106.43 & 32.50 & 590.39 \\
\hline 2016 & 62.80 & 75.28 & 31.45 & 513.68 \\
\hline
\end{tabular}

The analysis of one-base indices indicates that the Czech Republic. Poland and Slovakia are characterized by similar strength and directions of changes in the scope of the analyzed 
phenomenon. On the other hand, Hungary exceeds the increase in the number of bankruptcies in comparison to the other countries of the group in question. Starting from 2011, the increase in the number of bankruptcies exceeds to a large extent of $300 \%$ this number from the year taken as the basis for comparisons. On the contrary, Slovakia should be placed on the opposite side of the consideration as a country in which we observe a fall in the number of bankruptcies each year compared to the base year. The lowest value of the single-base index (26.45\%) Slovakia reached in 2008 and since then it has remained at a low level which does not exceed $41 \%$ in relation to 2005 .

Chain indices also indicate similarities between the Czech Republic, Poland and Slovakia, but different results for Hungary. The first three countries achieved the highest increase in the number of bankruptcies from the period to the period in 2009, and since 2014 they are characterized only by declines in this number. Hungary, on the other hand, reached its maximum not until 2011 and it is difficult to talk about any longer period of significant decreases in the analyzed period of time.

Having conducted the initial analysis, econometric trend models (Davidson, 2000) have been estimated. The number of bankruptcies of enterprises in individual countries of the Visegrad Group was used in the study as the dependent variable.

Polynomial trend models of the degree of $r$ have been considered and which take the following form:

$$
Y_{t}=\sum_{j=0}^{r} \alpha_{j} t^{j}+\eta_{t},
$$

where: $t$ - time variable $t=1,2, \ldots, n ; r$-degree of the polynomial of the time variable.

The choice of the polynomial degree was made by means of the $F$ test for equation of two variances (Greene, 2008). With the help of the classic least-squares method, appropriate models were estimated (Maddala \& Lahiri, 2009) describing the trend of bankruptcies of enterprises in individual countries. The obtained results are presented in Tables 4-7.

Table 4. The trend model of the bankruptcy in the Czech Republic in the years 2005-2016 (source: Own work)

\begin{tabular}{|c|c|c|}
\hline & coefficient & p value \\
\hline const & 1362.800 & 0.3383 \\
\hline $\mathrm{t}$ & 1743.730 & 0.0052 \\
\hline $\mathrm{t}^{2}$ & -140.424 & 0.0034 \\
\hline $\mathrm{R}^{2}$ & \multicolumn{2}{|c|}{0.6406} \\
\hline Rho1 & \multicolumn{2}{|c|}{-0.1649} \\
\hline
\end{tabular}

Table 5. The trend model of the bankruptcy in Poland in the years 2005-2016 (source: Own work)

\begin{tabular}{|c|c|c|}
\hline & coefficient & p value \\
\hline const & 1146.8900 & 0.0000 \\
\hline $\mathrm{t}$ & -448.3590 & 0.0000 \\
\hline
\end{tabular}


End of Table 5

\begin{tabular}{|c|c|c|}
\hline & coefficient & p value \\
\hline $\mathrm{t}^{2}$ & 88.3058 & 0.0000 \\
\hline $\mathrm{t}^{3}$ & -4.5681 & 0.0000 \\
\hline $\mathrm{R}^{2}$ & & 0.9650 \\
\hline Rho1 & \multicolumn{2}{|c|}{-0.1604} \\
\hline
\end{tabular}

Table 6. The trend model of the bankruptcy in Slovakia in the years 2005-2016 (source: Own work)

\begin{tabular}{|c|c|c|}
\hline & coefficient & p value \\
\hline const & 2717.4100 & 0.0000 \\
\hline $\mathrm{t}$ & -447.5610 & 0.0056 \\
\hline $\mathrm{t}^{2}$ & 24.4875 & 0.0270 \\
\hline $\mathrm{R}^{2}$ & & \\
\hline Rho1 & \multicolumn{2}{|c|}{0.7551} \\
\hline
\end{tabular}

Table 7. The trend model of the bankruptcy in Hungary in the years 2005-2016 (source: Own work)

\begin{tabular}{|c|c|c|}
\hline & coefficient & p value \\
\hline const & 26060.100 & 0.0254 \\
\hline $\mathrm{t}$ & -17867.000 & 0.0188 \\
\hline $\mathrm{t}^{2}$ & 4308.880 & 0.0037 \\
\hline $\mathrm{t}^{3}$ & -225.729 & 0.0031 \\
\hline $\mathrm{R}^{2}$ & \multicolumn{2}{|c|}{0.9339} \\
\hline Rho1 & -0.1900 \\
\hline
\end{tabular}

All presented trend models are characterized by a good adjustment to the empirical data. The R-squared coefficients of determination take values that exceed $75 \%$ in three models. Only for the Czech Republic this coefficient is lower and it amounts to about $64 \%$. The time variables included in them are statistically significant at the level not exceeding $3 \%$. There is no autocorrelation of the random component in the models and the residuals have a regular distribution (Maddala \& Lahiri, 2009). There is no autocorrelation because rhol value is under critical value in Quennouille (Box \& Jenkins, 1983) test. That mean that we shouldn't rejected null hypothesis. Null hypothesis says that is no autocorrelation of the random component in the model. Critical value of test is in our case equal $1.96 / \operatorname{sqrt}(12)=0.57$. The lack of autocorrelation is indicated by low values of the rhol coefficient. Their comparison to the limit value of the Quennouille test (Box \& Jenkins, 1983) indicates each time that there are no grounds for rejecting the zero hypothesis, which just speaks of the lack of this phenomenon. The limit value of the Quenouille test is 0.57 for the above models.

In addition, graphs of actual and fitted values for two models which are characterized by the best adjustment to the actual data will be presented. 


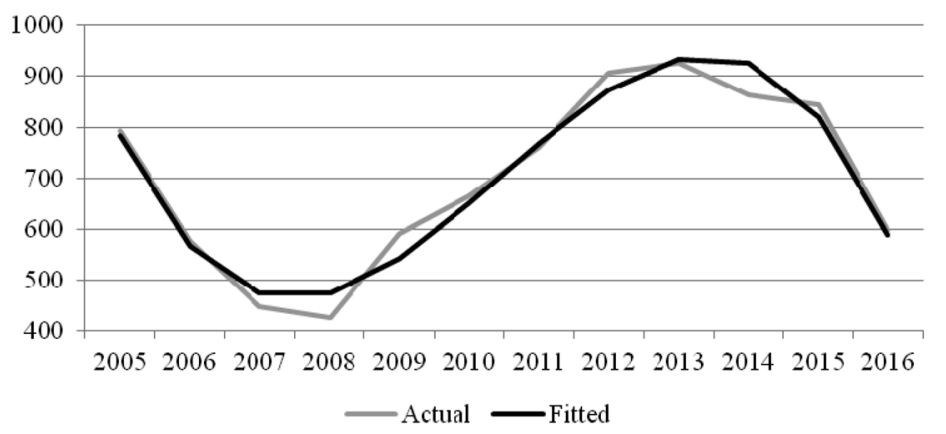

Figure 1. Actual and fitted values of the number of bankruptcy of enterprises in Poland obtained on the basis of the trend models (source: Own work)

From the estimated models of the enterprise bankruptcy trend we learn that within the scope of the conducted analysis the economies of the Czech Republic and Slovakia are best characterized by a quadratic function. For the Polish and Hungarian economies, the polynomial function of the third degree trend was the most appropriate one. This indicates the similarities occurring both in the first as well as in the other pair of countries of the Visegrad Group. Since in all four cases trends of higher degrees than the first (linear trend) were achieved, the obtained functional forms should not be interpreted from an economic point of view. Relatively high adjustment of the models to empirical data indicates the potential use of the estimated tools for forecasting the number of bankruptcies, especially in Poland and Hungary.

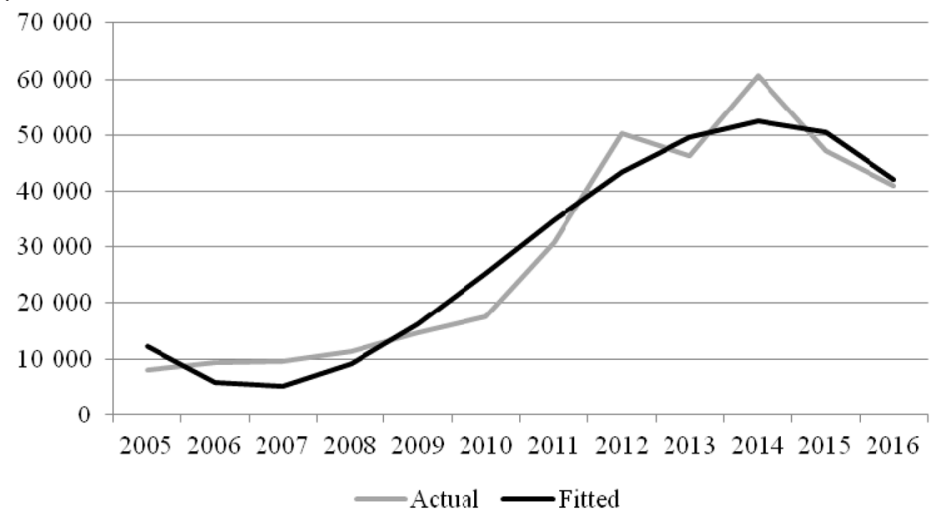

Figure 2. Actual and fitted values of the number of bankruptcy of enterprises in Hungary obtained on the basis of the trend models (source: Own work)

\section{The analysis of the effectiveness (efficiency) of the bankruptcy system of the Visegrad Group countries in relation to the European Union countries}

The research which enables to compare the effectiveness of bankruptcy systems between different countries has been implemented since 2003 by the World Bank as part of the "Doing Business" project. During the construction of the ranking within this research area, the 
following factors are taken into account: costs of the bankruptcy proceedings, their implementation time, debt recovery rate and the preference ratio for liquidation or reorganization bankruptcy proceedings.

The time of the bankruptcy process (in years - T) is the period from the submission of the application for liquidation of the company to the publication of the court verdict in this case. This value is a derivative of the bankruptcy procedures, their number and complexity in a given country as well as the possibility of conducting them simultaneously. This indicator also takes into account the time of appeals against decisions i.e. the appeals. The cost of bankruptcy (expressed in\% - C) is understood as the percentage value of the assets of the liquidated company. The cost is estimated on the basis of the actual results of research carried out by insolvency practitioners and it includes the following elements: court fees, fees of independent experts (appraisers), trustees, lawyers, attorneys as well as the accounting fees. The rate of return $(\mathrm{Rr})$ measures the number of cents obtained from the dollar recovered from the debtor through bankruptcy proceedings i.e. through either the reorganization or liquidation of an enterprise (Szmal-Kaptur, 2016).

The final results are obtained on the basis of data received from respondents who take part in the survey and who are regarded as experts in this field (Morawska, 2013). The ranking is created on the basis of the debt recovery rate which constitutes the main variable. Table 8 shows the basic information illustrating the effectiveness of bankruptcy systems in the European Union countries, including the Visegrad Group countries. The data were ordered according to the place in the ranking, with the total number of countries analyzed being equal to 183.

While analyzing the time, cost and rate of return in the "old" EU group (EU-15) and in the "new" EU group i.e. the group that includes the countries of the Visegrad Group (EU-13) the following regularities can be observed (Szmal-Kaptur, 2016):

- longer time of bankruptcy proceedings than in western countries i.e. three or more years for the majority of the surveyed countries, while in the Visegrad countries the longest duration of bankruptcy proceedings is: 4 years in Slovakia, 3 years in Poland, 2.1 years in the Czech Republic. The shortest two-year bankruptcy proceedings time was noted for Hungary.

- higher bankruptcy costs amounting up to $18 \%$ in Slovakia, $17 \%$ in the Czech Republic, $15 \%$ in Poland and $14.5 \%$ in Hungary - distinctly lower rate of return. The rate for the Czech Republic is $66 \%$ and it is the highest result for the V-4 countries. Poland achieves $57 \%$, Slovakia $54.7 \%$ and Hungary $41.7 \%$ rate of return. Finland, Slovenia, the Netherlands enjoy the highest rates of return at roughly $88-90 \%$.

The comparison of time, cost and the rate of return between two groups of countries i.e. the countries of the "old European Union" (EU-15) and the countries of the "new European Union", which include the countries of the Visegrad Group (EU-13), showed large discrepancies in the presented values.

The new EU countries, including the Visegrad Group countries, achieve worse results for the analyzed indicators, hence the conclusion that the implementation of EU bankruptcy law and international good bankruptcy practices significantly affects the improvement of national procedures and thus simplifies the process of the liquidation of an enterprise.

The analysis of the bankruptcy process of individual EU member states allowed to ascertain that the Visegrad Group countries are countries with ineffective bankruptcy system. 
This is mainly indicated by the low rate of return in the bankruptcy proceedings as well as by their high costs and the long liquidation period of the enterprise.

Other studies which allow to compare European bankruptcy systems have been carried out by the European Commission and they were presented in the document entitled "Business Dynamics: Start-ups, Business Transfers and Bankruptcy". The research was conducted in the form of interviews and questionnaires as well as the analyses of literature and statistical data. The studies included 27 EU countries as well as Croatia, Montenegro, Iceland, Norway,

Table 8. The effectiveness of bankruptcy proceedings in the European Union countries in 2016 (source: Kupis, 2017)

\begin{tabular}{|c|c|c|c|}
\hline Country & $\begin{array}{l}\text { The rate of satisfaction of the } \\
\text { creditors' claims } \\
\text { (in percentages) }\end{array}$ & $\begin{array}{l}\text { The duration of } \\
\text { the bankruptcy } \\
\text { proceedings } \\
\text { (in years) }\end{array}$ & $\begin{array}{l}\text { The cost of the } \\
\text { bankruptcy proceedings } \\
\text { (as a percentage of the } \\
\text { bankrupt's assets) }\end{array}$ \\
\hline Austria & 82.7 & 1.1 & 10.0 \\
\hline Belgium & 89.3 & 0.9 & 3.5 \\
\hline Bulgaria & 34.0 & 3.3 & 9.0 \\
\hline Croatia & 30.5 & 3.1 & 14.5 \\
\hline Cyprus & 71.4 & 1.5 & 14.5 \\
\hline Czech Republic & 66.0 & 2.1 & 17.0 \\
\hline Denmark & 87.8 & 1.0 & 4.0 \\
\hline Estonia & 40.0 & 3.0 & 9.0 \\
\hline Finland & 90.1 & 0.9 & 3.5 \\
\hline France & 77.5 & 1.9 & 9.0 \\
\hline Germany & 83.7 & 1.2 & 8.0 \\
\hline Greece & 34.9 & 3.5 & 9.0 \\
\hline Hungary & 41.7 & 2.0 & 14.5 \\
\hline Ireland & 87.7 & 0.4 & 9.0 \\
\hline Italy & 63.1 & 1.8 & 22 \\
\hline Latvia & 41.7 & 1.5 & 10.0 \\
\hline Lithuania & 42.8 & 2.3 & 10.0 \\
\hline Luxembourg & 43.8 & 2.0 & 14.5 \\
\hline Malta & 39.6 & 3.0 & 10.0 \\
\hline Netherlands & 88.9 & 1.1 & 3.5 \\
\hline Poland & 58.3 & 3.0 & 15.0 \\
\hline Portugal & 73.4 & 2.0 & 9.0 \\
\hline Romania & 32.7 & 3.3 & 10.5 \\
\hline Slovakia & 54.7 & 4.0 & 18.0 \\
\hline Slovenia & 88.2 & 0.8 & 4.0 \\
\hline Spain & 71.2 & 1.5 & 11.0 \\
\hline Sweden & 76.6 & 2.0 & 9.0 \\
\hline
\end{tabular}


Turkey and Serbia. The research period covered 12 months, from November 2009 to the end of October 2010. Table 9 shows the basic characteristics of the individual bankruptcy systems such as the effectiveness of the early warning system, the effectiveness of out-of-court procedures as well as whether the bankruptcy system was debtor/creditor friendly or whether the bankruptcy law system was biased towards reorganization (restructuring) or liquidation of an enterprise. The data were based on the responses received from the respondents.

When analyzing the data shown in Table 9 for the Visegrad Group countries, the following conclusions can be drawn:

- in the Czech Republic the effectiveness of the early warning system is low and its bankruptcy system is friendly to creditors but there is a lack of data regarding the effectiveness of out-of-court proceedings;

- in Hungary there is a low level of efficiency of the early warning system, a low degree of the reorganization bias and the remaining elements of the analysis lack data;

- in Slovakia there is high efficiency of the early warning system, very high efficiency of out-of-court procedures and a neutral bankruptcy system for debtors /creditors;

- in Poland there is an average level of the effectiveness of the early warning system, the effectiveness of out-of-court procedures is very low, the bankruptcy system is friendly to creditors and, once the bankruptcy law reform was introduced in 2016, the system is biased towards reorganization.

Table 9. The characteristics of bankruptcy systems in selected European countries (source: European Commission, 2011)

\begin{tabular}{|c|c|c|c|c|c|}
\hline Country & $\begin{array}{c}\text { The origin of } \\
\text { the Bankruptcy } \\
\text { Law }\end{array}$ & $\begin{array}{c}\text { The } \\
\text { effectiveness } \\
\text { of the early } \\
\text { warning } \\
\text { system }\end{array}$ & $\begin{array}{c}\text { The } \\
\text { effectiveness } \\
\text { of the out- } \\
\text { of-court } \\
\text { proceedings }\end{array}$ & $\begin{array}{l}\text { The Bankruptcy } \\
\text { Law system } \\
\text { friendly to debtors/ } \\
\text { creditors }\end{array}$ & $\begin{array}{l}\text { The Bankruptcy } \\
\text { Law system } \\
\text { biased towards } \\
\text { reorganisation / } \\
\text { liquidation }\end{array}$ \\
\hline Austria & $\begin{array}{l}\text { German Civil } \\
\text { Law }\end{array}$ & low & low & debtors' friendly & reorganization \\
\hline Belgium & $\begin{array}{l}\text { French Civil } \\
\text { Law }\end{array}$ & low & N/A & N/A & N/A \\
\hline Bulgaria & $\begin{array}{l}\text { Combination } \\
\text { of German and } \\
\text { French Civil } \\
\text { Law }\end{array}$ & low & low & debtors' friendly & N/A \\
\hline Croatia & $\begin{array}{l}\text { German Civil } \\
\text { Law }\end{array}$ & & very low & creditors' friendly & N/A \\
\hline Cyprus & $\begin{array}{l}\text { Pluralistic } \\
\text { Rule of Law - } \\
\text { combination of } \\
\text { Common Law } \\
\text { and Civil Law }\end{array}$ & average & low & creditors' friendly & N/A \\
\hline $\begin{array}{l}\text { Czech } \\
\text { Republic }\end{array}$ & $\begin{array}{l}\text { German Civil } \\
\text { Law }\end{array}$ & low & N/A & creditors' friendly & N/A \\
\hline Denmark & $\begin{array}{l}\text { Scandinavian } \\
\text { Civil Law }\end{array}$ & high & high & neutral & N/A \\
\hline
\end{tabular}


Continued Table 9

\begin{tabular}{|c|c|c|c|c|c|}
\hline Country & $\begin{array}{c}\text { The origin of } \\
\text { the Bankruptcy } \\
\text { Law }\end{array}$ & $\begin{array}{c}\text { The } \\
\text { effectiveness } \\
\text { of the early } \\
\text { warning } \\
\text { system }\end{array}$ & $\begin{array}{l}\text { The } \\
\text { effectiveness } \\
\text { of the out- } \\
\text { of-court } \\
\text { proceedings }\end{array}$ & $\begin{array}{c}\text { The Bankruptcy } \\
\text { Law system } \\
\text { friendly to debtors/ } \\
\text { creditors }\end{array}$ & $\begin{array}{c}\text { The Bankruptcy } \\
\text { Law system } \\
\text { biased towards } \\
\text { reorganisation / } \\
\text { liquidation }\end{array}$ \\
\hline Estonia & $\begin{array}{l}\text { German Civil } \\
\text { Law }\end{array}$ & high & low & neutral & N/A \\
\hline Finland & $\begin{array}{l}\text { Scandinavian } \\
\text { Civil Law }\end{array}$ & high & high & debtors' friendly & $\begin{array}{l}\text { low bias towards } \\
\text { reorganisation }\end{array}$ \\
\hline France & $\begin{array}{l}\text { French Civil } \\
\text { Law }\end{array}$ & average & high & debtors' friendly & reorganization \\
\hline Germany & German Law & vey high & average & neutral & N/A \\
\hline Greece & $\begin{array}{l}\text { French Civil } \\
\text { Law }\end{array}$ & low & low & creditors' friendly & N/A \\
\hline Hungary & $\begin{array}{l}\text { Combination } \\
\text { of German and } \\
\text { French Civil } \\
\text { Law }\end{array}$ & low & N/A & N/A & $\begin{array}{l}\text { low bias } \\
\text { towards } \\
\text { reorganisation }\end{array}$ \\
\hline Iceland & $\begin{array}{l}\text { Scandinavian } \\
\text { Civil Law }\end{array}$ & low & high & debtors' friendly & N/A \\
\hline Ireland & Common Law & low & very low & neutral & $\begin{array}{l}\text { low bias towards } \\
\text { reorganisation }\end{array}$ \\
\hline Italy & \begin{tabular}{|l} 
French Civil \\
Law
\end{tabular} & low & low & creditors' friendly & N/A \\
\hline Latvia & $\begin{array}{l}\text { German Civil } \\
\text { Law }\end{array}$ & low & very low & creditors' friendly & N/A \\
\hline Lithuania & $\begin{array}{l}\text { Combination } \\
\text { of German and } \\
\text { French Civil } \\
\text { Law }\end{array}$ & high & very low & creditors' friendly & N/A \\
\hline Luxembourg & $\begin{array}{l}\text { French Civil } \\
\text { Law }\end{array}$ & N/A & N/A & N/A & N/A \\
\hline Malta & $\begin{array}{l}\text { Pluralistic } \\
\text { Rule of Law - } \\
\text { combination of } \\
\text { Common Law } \\
\text { and Civil Law }\end{array}$ & low & N/A & N/A & N/A \\
\hline Montenegro & $\begin{array}{l}\text { German Civil } \\
\text { Law }\end{array}$ & average & average & creditors' friendly & N/A \\
\hline Netherlands & $\begin{array}{l}\text { French Civil } \\
\text { Law }\end{array}$ & high & high & creditors' friendly & $\begin{array}{l}\text { low bias towards } \\
\text { reorganisation }\end{array}$ \\
\hline Norway & $\begin{array}{l}\text { Scandinavian } \\
\text { Civil Law }\end{array}$ & low & low & creditors' friendly & $\begin{array}{l}\text { low bias towards } \\
\text { reorganisation }\end{array}$ \\
\hline Poland & $\begin{array}{l}\text { French Civil } \\
\text { Law }\end{array}$ & average & very low & creditors' friendly & reorganization \\
\hline
\end{tabular}


End of Table 9

\begin{tabular}{|c|c|c|c|c|c|}
\hline Country & $\begin{array}{c}\text { The origin of } \\
\text { the Bankruptcy } \\
\text { Law }\end{array}$ & $\begin{array}{c}\text { The } \\
\text { effectiveness } \\
\text { of the early } \\
\text { warning } \\
\text { system }\end{array}$ & $\begin{array}{l}\text { The } \\
\text { effectiveness } \\
\text { of the out- } \\
\text { of-court } \\
\text { proceedings }\end{array}$ & $\begin{array}{c}\text { The Bankruptcy } \\
\text { Law system } \\
\text { friendly to debtors/ } \\
\text { creditors }\end{array}$ & $\begin{array}{l}\text { The Bankruptcy } \\
\text { Law system } \\
\text { biased towards } \\
\text { reorganisation / } \\
\text { liquidation }\end{array}$ \\
\hline Portugal & $\begin{array}{l}\text { French Civil } \\
\text { Law }\end{array}$ & low & low & neutral & N/A \\
\hline Romania & $\begin{array}{l}\text { French Civil } \\
\text { Law }\end{array}$ & average & low & N/A & N/A \\
\hline Serbia & $\begin{array}{l}\text { French Civil } \\
\text { Law }\end{array}$ & low & low & creditors' friendly & N/A \\
\hline Slovakia & $\begin{array}{l}\text { German } \\
\text { Civil Law }\end{array}$ & high & very high & neutral & N/A \\
\hline Slovenia & $\begin{array}{l}\text { German Civil } \\
\text { Law }\end{array}$ & & average & neutral & N/A \\
\hline Spain & $\begin{array}{l}\text { French Civil } \\
\text { Law }\end{array}$ & low & high & creditors' friendly & reorganization \\
\hline Sweden & $\begin{array}{l}\text { Scandinavian } \\
\text { Civil Law }\end{array}$ & low & high & neutral & $\begin{array}{l}\text { low bias towards } \\
\text { reorganisation }\end{array}$ \\
\hline Turkey & $\begin{array}{l}\text { German Civil } \\
\text { Law }\end{array}$ & N/A & N/A & N/A & N/A \\
\hline $\begin{array}{l}\text { Great } \\
\text { Britain }\end{array}$ & Common Law & very high & very high & creditors' friendly & reorganization \\
\hline
\end{tabular}

Due to the political and economic changes, the institution of bankruptcy in the countries of Central and Eastern Europe began to function in the first half of the 1990s. During this period, the first cases of bankruptcy emerged.

The Visegrad Four countries are connected not only by their histories but also by their common endeavours in the economic, political and cultural fields. A similar historical development among these post-communist countries is reflected in the development of their insolvency laws. All analyzed countries had to reform their insolvency laws after 1990 (Venyš, 1997; Janda \& Rakicova, 2014; Aghion et al., 1994; Gerlach, 1998). Because insolvency proceedings in the V4 countries were considered highly inefficient the insolvency systems of the Visegrad Four countries have recently been re-codified. At present, the insolvency systems of the V4 countries are largely similar. The insolvent state of business entities in these countries should be solved in two basic ways i.e. reorganization or liquidation. The only difference is in the naming of these ways in the different countries. In Poland, there is also the possibility of applying for out-of court reorganization, which means lower costs of proceedings (Crhova et al., 2016).

Insolvency of enterprises in V4 countries is an important problem that requires a solution. Its negative signs include limiting possibilities of the growth of enterprises, reduction in takings and profits, lowering of liquidity, growth of interest costs as well as workforce reductions. Creating an appropriate legal framework along with the implementation of ethics in business enable the stabilization of the insolvency system (Bobákova, 2016). The effort 
to establish efficient insolvency proceedings is now being undertaken in each V4 country. If the enterprise is still salvageable, the best option appears to be reorganization that preserves jobs. However, if the rescue of the enterprise is no longer possible, bankruptcy proceedings are opened. Effectively set insolvency proceedings are one of the ways of improving the competitiveness of the country.

The predictability of law is crucial for the functioning of all economic subjects, both for those in insolvency and those which are prospering.

\section{Discussion}

In the empirical part of the paper, it was possible to calculate one-base and chain indices of dynamics which constitute the basic statistical apparatus for the analysis of changes over time occurring in variables in the form of time series. The results of the calculations showed similarities between 3 countries. Hungary was a country that proved to be different from the others.

Having conducted the statistical analysis, the basic econometric analysis was carried out in the form of specification and estimation of the trend models of the bankruptcy of enterprises in the Visegrad group members. Polynomial row trend models from the first to the third were specified and estimated. Thus, a total of 12 models were estimated, out of which a few the best from the statistical point of view were selected and presented. Here, it turned out that similarities can be observed among pairs of countries i.e. the Czech Republic obtained the same degree of trend as Slovakia and Poland obtained the same degree of trend as Hungary.

From the point of view of the analysis of the dynamics and its similarities among the members of the Visegrad group, the authors deem the analysis satisfactory. The selected models may find empirical application to forecast the number of bankruptcies of enterprises in the analyzed economies. However, the following issues shall be kept in mind:

- the increase in the number of observations considered in the analyzed time seriesmay result in a change in the obtained results;

- the extension of the set of variables with potential explanatory variables could enrich the analysis in terms of the cause and effect relationships occurring in the field of bankruptcy of enterprises in the analyzed group of countries.

Nevertheless, it is impossible to do that only on the basis of the statistical material collected so far. The authors are considering extending the analysis of the above issues in their further work, as this article obviously does not exhaust the subject which shall be developed on an ongoing basis.

\section{Conclusions}

The issue of the bankruptcy of enterprises is an important area of empirical research, which is confirmed by numerous scientific studies. The phenomenon of bankruptcy is an extremely complex problem and it can be considered from different points of view. The substantive values of this publication are as follows: the ability to address the problem (deep approach), 
the retrospective and critical review of the selected (extensive) literature on the subject, the appropriate adjustment of the empirical layer within which the relationships between the studied phenomena have been established.

This paper may provide the impetus for further research in this matter. The significance of bankruptcy in the contemporary economy is evidenced by the scale and dynamics of this phenomenon and the fact of taking into account the effectiveness of bankruptcy proceedings in assessing the efficiency of national economies. Therefore, the Authors believe that in the future it would be reasonable to conduct research on the effectiveness of bankruptcy systems of the Visegrad Group countries in terms of formulating responses to the following issues:

- the comparative analysis of bankruptcy systems of the Visegrad Group countries with respect to the European Union countries and with particular consideration given to the duration of bankruptcy proceedings, the cost of bankruptcy and the rate of return of the recovered receivables;

- the analysis of the impact of macroeconomic and microeconomic factors on the scale and the dynamics of bankruptcies of enterprises of the Visegrad Group countries;

- the analysis of changes in the provisions of law regarding bankruptcy proceedings in order to increase the efficiency of bankruptcy proceedings of the Visegrad Group countries;

- the analysis of the impact of the Second chance policy implemented in the countries of the European Union on the improvement of the efficiency of the bankruptcy systems of the Visegrad Group countries.

Although bankruptcies are not a mass phenomenon, they occur often enough so that they cannot be deemed irrelevant. The bankruptcy statistics presented in this paper regarding the economies of the Visegrad Group countries constitute a strong confirmation of the significant scale of the bankruptcy of enterprises.

\section{Disclosure statement}

The authors (Jarosław Krajewski, Andrzej Tokarski and Maciej Tokarski) have NO affiliations with or involvement in any organization or entity with any financial interest (such as honoraria; educational grants; participation in speakers' bureaus; membership, employment, consultancies, stock ownership, or other equity interest; and expert testimony or patent-licensing arrangements), or non-financial interest (such as personal or professional relationships, affiliations, knowledge or beliefs) in the subject matter or materials discussed in this manuscript.

\section{References}

Aczel, A. D. (2012). Complete busines statistics. Wohl Publishing. Inc.

Aghion, P., Hart, O., \& Moore, J. (1994). The economics of bankruptcy reforms. National Bureau of Economic Research - Transition in Eastern Europe, 2, 215-244. http://www.nber.org/chapters/c6727.pdf

Altman, E. I., \& Hotchkiss, E. (2006). Corporate financial distress and bankruptcy - Predict and avoid bankruptcy, analyze and invest in distress debt ( $3^{\text {th }}$ ed.). John Wiley \& Sons. https://doi.org/10.1002/9781118267806

Baltagi, B. H. (2001). A companion to theoretical econometrics. Blackwel Publishers Ltd. 
Baun, M. J., \& Marek, D. (2010). Czech foreign policy and EU integration: European and Domestic sources. Perspectives on European Politics and Society, 11(1), 2-21. https://doi.org/10.1080/15705850903553513

Bobáková, V. (2016). Insolvency of enterprises. Enterprise and Finance, 2(13). http://pif.wsfiz.edu.pl/wp-content/uploads/2018/11/PiF_2016_213.pdf

Box, G. E. P., \& Jenkins, G. M. (1983). Time series analysis. PWN.

Bukalska, P. (2003). A New Visegrad Group in New European Union - Possibilities and opportunities for development. Centre for Eastern Studies, Warsaw.

https://www.files.ethz.ch/isn/90290/new_visegrad_group.pdf

European Commission. (2011, January). Business dynamics: Start-ups, business transfers and bankruptcy (Final Report). Bruxelles, 185-186.

Creditreform. (2018). Creditreform.de. Retrieved January 8, 2018 from https://www.creditreform.at/ presse/insolvenzstatistik-europa.html

Crhova, Z., Fišerova, Z, \& Pasekova, Z. (2016). Corporate insolvency proceedings: A case of Visegrad Four. Acta Universitatis Agriculturae et Silviculturae Mendelianae Brunensis, 64(1), 235-243. https://doi.org/10.11118/actaun201664010235

Dangerfield, M. (2014). V4: A new brand for Europe? Ten years of post-accession regional cooperation in Central Europe. The Poznan University of Economics Review, 14(4), 71-90.

https://www.ebr.edu.pl/pub/2014_4_71.pdf

Dangerfield, M. (2005). The Visegrad Group in the expanded European Union: From preaccession to postaccession cooperation. East European Politics and Societies, 22(3), 630-667. https://doi.org/10.1177/0888325408315840

Davidson, J. (2000). Econometric theory. Publishers Ltd. Oxford.

Durica, M., Frnda, J., \& Svabova, L. (2019). Decision tree based model of business failure prediction for Polish companies. Oeconomia Copernicana, 10(3), 453-469. https://doi.org/10.24136/oc.2019.022

Durica, M., Valaskova, K., \& Janoskova, K. (2019). Logit business failure prediction in V4 countries. Engineering Management in Production and Services, 11(4), 54-64. https://doi.org/10.2478/emj-2019-0033

Gerlach, H. (1998). Bankruptcy in the Czech Republic, Hungary, and Poland and Section 304 of the United States Bankruptcy Code. Proceedings Ancillary to Foreign Bankruptcy Proceedings. Maryland Journal of International Law, 22(1). http://digitalcommons.law.umaryland.edu/mjil/vol22/iss1/4

Greene, W. H. (2008). Econometric analysis. Pearson Education Inc.

Hart, O. (2000). Different approaches to bankruptcy (Harvard Institute of Economic Research Paper No. 1903). https://doi.org/10.2139/ssrn.241066

Jagodzinski, A. (Ed.). (2006). The Visegrad Group - A Central European Constellation. Publication on the Occasion of the $15^{\text {th }}$ Anniversary of the Visegrad Group. International Visegrad Fund, Bratislava. http://www.visegradgroup.eu/the-visegrad-book/the-visegrad-group-110412

Janda, K., \& Rakicova, A. (2014). Corporate bankruptcies in Czech Republic, Slovakia, Croatia and Serbia (MPRA Paper No. 54109). University of Economics, Prague. https://mpra.ub.uni-muenchen.de/54109/1/MPRA_paper_54109.pdf

Kliestik, T., Vrbka, J., \& Rowland, Z. (2018). Bankruptcy prediction in Visegrad group countries using multiple discriminant analysis. Equilibrium. Quarterly Journal of Economics and Economic Policy, 13(3), 569-593 https://doi.org/10.24136/eq.2018.028

Kořan, M. (2012). The Visegrad group on the threshold of its third decade: A Central European Hub? In Z. Šabič \& P. Drulák, (Eds.), Regional and international relations of Central Europe (pp. 201-218). Palgrave Macmillan. https://doi.org/10.1057/9781137283450_11

Kupis, P. (2017). Dysfunkcje postępowań upadłościowych - perspektywa wierzycieli. Biuletyn PTE, 2(77), s. 39. http://www.pte.pl/pliki/1/68/Biuletyn_2_2017.pdf 
Mačerinskienè, I., \& Mendelsonas, T. (2013). Macroeconomic determinants of corporate insolvency. KSI Transactions on Knowledge Society, 6(3), 35-40.

Maddala, G. S., \& Lahiri, K. (2009). Introduction to econometrics. Wiley.

Matuszak, M., \& Tokarski, A. (2016). The presentation of and reasons for the bankruptcy of enterprises in the Kuyavian-Pomeranian Voivodeship in the years 2008-2015. In S. Rudolf, The new institutional economics and management sciences (Vol. 48). Scientific Works of the School of Banking in Gdańsk.

Matuszak, M., \& Tokarski, A. (2016a). Bankruptcy and its importance in a market economy - an institutional approach. In S. Rudolf, The new institutional economics and management sciences (Vol. 48). Scientific Works of the School of Banking in Gdańsk.

Mączyńska, E., \& Morawska, S. (2015). The effectiveness of the bankruptcy proceedings. The bankruptcy of the enterprises. Catharsis and the new chance. SGH, Warsaw.

Mączyńska, E (Ed.). (2013). Bankruptcy and recovery processes in Poland in view of the European Union's experiences. SGH, Warsaw.

Morawska, S. (2013). Businessman in the face of bankruptcy. SGH, Warsaw.

Piotrowicz, W. (2015) Information technology and systems in the Visegrád Group of countries (Czech Republic, Hungary, Poland, and Slovakia): A literature review. Journal of Global Information Technology Management, 18(2), 77-93. https://doi.org/10.1080/1097198X.2015.1052684

Prusak, B. (2018). Review of research into enterprise bankruptcy prediction in selected Central and Eastern European countries. International Journal of Financial Studies, 6(3), 60. https://doi.org/10.3390/ijfs6030060

Ručinská, S., \& Fečko, M. (2016). The past and future of the European Union Internal Market - Visegrad Group Perspective. Central European Papers, 4(1), 82-94). https://doi.org/10.25142/cep.2016.007

Szmal-Kaptur, J. (2016). Company bankruptcy in Poland and other European Union countries in the period 2005-2014. Cracow Review of Economics and Management, 2(950), 5-21. https://doi.org/10.15678/ZNUEK.2016.0950.0201

Tokarski, A., \& Matuszak, M. (2016). Upadłość jako instytucja gospodarki rynkowej [Bankruptcy as an institution of the market economy]. Przedsiębiorczość - Edukacja [Entrepreneurship-Education], 12, 199-216. https://doi.org/10.24917/3149

Tokarski, A., \& Tokarski, M. (2019). Przebieg procesu upadłościowego przedsiębiorstw polskich w XXI w. [The Course of the Bankruptcy Process of Polish Enterprises in the 21st Century]. Przedsiębiorczość-Edukacja [Entrepreneurship-Education], 15(2), 248-263. https://doi.org/10.24917/20833296.152.17

Tokarski, A., \& Tokarski, M. (2018). The influence of the macroeconomic factors on the scale and dynamics of the bankruptcy of enterprises in the Polish economy in the years 2000-2015. Transformations in Business \& Economics, 17(2A), 337-352.

Tokarski, A. (2018). The phenomenon of bankruptcy of enterprises in the Polish economy in the years 2008-2015. In E. Lotko, U. K. Zawadzka-Pąk, \& M. Radvan (Eds.), Optimization of organization and legal solutions concerning public revenues and expenditures in public interest (pp. 403-420). Conference Proceedings. Białystok-Vilnius, Themis 2. https://doi.org/10.15290/oolscprepi.2018.30

Tomczak, S. (2018). Statistics on bankruptcy of companies in Poland. Managment Sciences, 23(3), 3950. https://doi.org/10.15611/ms.2018.3.05

Venyš, L. (1997). Bankruptcy in the Czech Republic. NATO democratic institutions fellowship programme 1995-1997. http://www.nato.int/acad/fellow/95-97/venys.pdf

Wang, C. (2006, July). Law and bankruptcy: An international comparison of liquidation and reorganization. Asian Financial Association/Financial Management Association. Annual Conference Proceedings. Auckland, New Zealand. 